\title{
Processus and recessus adhaerentes: giant adherens cell junction systems connect and attract human mesenchymal stem cells
}

\author{
Patrick Wuchter • Judit Boda-Heggemann • \\ Beate K. Straub • Christine Grund • Caecilia Kuhn • \\ Ulf Krause • Anja Seckinger • Wiebke K. Peitsch • \\ Herbert Spring • Anthony D. Ho • Werner W. Franke
}

Received: 11 November 2006 / Accepted: 10 January 2007 / Published online: 20 March 2007

(C) Springer-Verlag 2007

\begin{abstract}
Substrate-adherent cultured cells derived from human bone marrow or umbilical cord blood ("mesenchy-

Patrick Wuchter and Judit Boda-Heggemann contributed equally to this work.

This work was supported in part by the Joachim Siebeneicher Foundation, by the Deutsche Forschungsgemeinschaft (grant HO 914/ 4-1 to A.D.H.), by the Deutsche Krebshilfe (grant 10-2049-Fr 1 to W. W.F), and by a grant from the German Ministry for Research and Technology in the special funding program "Regenerative Medicine" ("START-MSC", grants to A.D.H. and W.W.F).
\end{abstract}

P. Wuchter $\cdot$ U. Krause $\cdot$ A. Seckinger · A. D. Ho

Department of Internal Medicine V,

University of Heidelberg,

Im Neuenheimer Feld 410,

69120 Heidelberg, Germany

J. Boda-Heggemann • B. K. Straub • C. Grund · C. Kuhn •

W. W. Franke $(\bowtie)$

Division of Cell Biology/A010,

German Cancer Research Center (DKFZ),

Im Neuenheimer Feld 280,

69120 Heidelberg, Germany

e-mail: w.franke@dkfz.de

W. K. Peitsch

Department of Dermatology, Mannheim Medical Center,

University of Heidelberg,

Mannheim, Germany

\section{H. Spring}

Division of Biomedical Structure Analysis Group,

German Cancer Research Center (DFKZ),

Im Neuenheimer Feld 280,

69120 Heidelberg, Germany

Present address:

J. Boda-Heggemann

Department of Radiation Oncology,

Mannheim Medical Center, University of Heidelberg,

Mannheim, Germany mal stem cells") are of special interest for regenerative medicine. We report that such cells, which can display considerable heterogeneity with respect to their cytoskeletal protein complement, are often interconnected by special tentacle-like cell processes contacting one or several other cells. These processus adhaerentes, studded with many (usually small) puncta adhaerentia and varying greatly in length (up to more than $400 \mu \mathrm{m}$ long), either contact each other in the intercellular space ("ET touches") or insert in a tight-fitting manner into deep plasma membrane invaginations (recessus adhaerentes), thus forming a novel kind of long (up to $50 \mu \mathrm{m}$ ) continuous cuff-like junction (manubria adhaerentia). The cell processes contain an actin microfilament core that is stabilized with ezrin, $\alpha$-actinin, and myosin and accompanied by microtubules, and their adhering junctions are characterized by a molecular complement comprising the transmembrane glycoproteins $\mathrm{N}$-cadherin and cadherin-11, in combination with the cytoplasmic plaque proteins $\alpha$ - and $\beta$-catenin, together with $\mathrm{p} 120^{\mathrm{ctn}}$, plakoglobin, and afadin. The processes are also highly dynamic and rapidly foreshorten as cell colonies approach a denser state of cell packing. These structures are obviously able to establish cell-cell connections, even over long distances, and can form deep-rooted and tight cell-cell adhesions. The possible relationship to similar cell processes in the embryonic primary mesenchyme and their potential in cell sorting and tissue formation processes in the body are discussed.

Keywords Stem cells · Adhering junctions · Cadherins · Cell contacts $\cdot$ Cell processes $\cdot$ Human 
Table 1 Primary antibodies used ( $m A b$ monoclonal antibody, $A s$ conventionally prepared antiserum or $\operatorname{IgG}$ prepared therefrom, $r b$ rabbit, $m$ mouse, $g$ goat, $g p$ guinea pig)

\begin{tabular}{|c|c|c|}
\hline Antigen & Antibody type & Source (reference) \\
\hline \multicolumn{3}{|l|}{ Cadherins } \\
\hline \multirow[t]{3}{*}{$\mathrm{N}$-Cadherin } & a) $\mathrm{mAb}, \mathrm{m}$ & Transduction Laboratories, Lexington, Ky., USA \\
\hline & b) As, rb & R\&D Systems, Minneapolis, Minn., USA \\
\hline & c) $\mathrm{mAb}, \mathrm{m}(\mathrm{A}-\mathrm{CAM})$ & Gift of B. Geiger, Weizmann Institute, Rehovot, Israel \\
\hline \multirow[t]{3}{*}{ VE-Cadherin } & a) mAb, m (BV9) & Gift of E. Dejana, University of Milan, Italy \\
\hline & b) $\mathrm{mAb}, \mathrm{m}$ & Transduction Laboratories \\
\hline & c) As, rb & Alexis Biochemicals, Grünberg, Germany \\
\hline R-Cadherin & $\mathrm{mAb}, \mathrm{m}$ & BD Biosciences, San Jose, Calif., USA \\
\hline M-Cadherin & $\mathrm{mAb}, \mathrm{g}$ & RDI (Research Diagnostics), Flanders, N.J., USA \\
\hline \multirow[t]{2}{*}{ Cadherin 11} & a) $\mathrm{mAb}, \mathrm{m}$ & Zymed Laboratories, South San Francisco, Calif., USA \\
\hline & b) As, rb & Zymed \\
\hline E-Cadherin & $\mathrm{mAb}, \mathrm{m}$ & Transduction Laboratories \\
\hline P-Cadherin & $\mathrm{mAb}, \mathrm{m}$ & Transduction Laboratories \\
\hline T-Cadherin & As, rb & Santa Cruz Biotechnology, Santa Cruz, Calif., USA \\
\hline Cadherin 8 & As, g & Santa Cruz Biotechnology \\
\hline LI-Cadherin & As, $g$ & Santa Cruz Biotechnology \\
\hline OB-Cadherin 2 & As, $\mathrm{g}$ & Santa Cruz Biotechnology \\
\hline Cadherin 6 & $\mathrm{mAb}, \mathrm{m}$ & US Biologicals, Swampscott, Mass., USA \\
\hline Desmogleins 1-2 & $\mathrm{mAb}, \mathrm{DG} 3.10$ & Progen Biotechnik, Heidelberg, Germany \\
\hline Desmocollins $1-3$ & As, rb & Natutec, Frankfurt/M, Germany \\
\hline \multicolumn{3}{|l|}{ Arm-repeat proteins } \\
\hline \multirow[t]{2}{*}{ Plakoglobin } & a) mAb, m (11E4) & Gift of M.J. Wheelock, University of Nebraska, Omaha, Neb., USA \\
\hline & b) $\mathrm{mAb}, \mathrm{m}(\mathrm{PG} 5.1)$ & Progen \\
\hline \multirow[t]{2}{*}{$\beta$-Catenin } & a) As, rb & Sigma, St. Louis, Mo., USA \\
\hline & b) $\mathrm{mAb}, \mathrm{m}$ & Transduction Laboratories \\
\hline Protein $\mathrm{p} 120^{\mathrm{ctn}}$ & $\mathrm{mAb}, \mathrm{m}$ & Transduction Laboratories \\
\hline Plakophilin 1 & $\mathrm{mAb}, \mathrm{m}(5 \mathrm{C} 2)$ & Progen \\
\hline Plakophilin 2 & $\mathrm{mAb}, \mathrm{m}(\mathrm{CM} 150)$ & Progen (Mertens et al. 1996) \\
\hline Plakophilin 3 & $\mathrm{mAb}, \mathrm{m}(270.6 .2)$ & Progen \\
\hline Neurojungin & $\mathrm{mAb}, \mathrm{m}(\mathrm{J} 19)$ & Progen (Paffenholz et al. 1999) \\
\hline \multicolumn{3}{|l|}{ Other plaque proteins } \\
\hline \multirow[t]{2}{*}{$\alpha$-Catenin } & a) As, rb & Sigma \\
\hline & b) $\mathrm{mAb}, \mathrm{m}$ & Transduction Laboratories \\
\hline \multirow[t]{2}{*}{ Desmoplakin (DP) } & a) As, rb & Natutec \\
\hline & b) mAb, m, DP I\&II $(2.15,2.17,2.20)$ & Progen \\
\hline Vinculin & $\mathrm{mAb}, \mathrm{m}(\operatorname{vin} 11-5)$ & Sigma \\
\hline$\alpha$-Actinin & $\mathrm{mAb}, \mathrm{m}$ & Sigma \\
\hline \multicolumn{3}{|c|}{ Nectin-afadin complex } \\
\hline Nectin 2 & mAb, m (PRR-2) & Diaclone, Besançon, France \\
\hline L/s-afadin & As, rb & Sigma \\
\hline \multicolumn{3}{|c|}{ Tight-junctional proteins } \\
\hline Claudin $1-5$ & As, rb & Zymed \\
\hline \multirow[t]{2}{*}{ Occludin } & a) $\mathrm{mAb}$ & Zymed \\
\hline & b) As, rb & Zymed \\
\hline JAM-1 & $\mathrm{mAb}, \mathrm{m}$ & Transduction Laboratories \\
\hline $\mathrm{ZO}-1$ & As, rb & Zymed \\
\hline $\mathrm{ZO}-2$ & As, rb & Zymed \\
\hline Symplekin & $\mathrm{mAb}, \mathrm{m}(\mathrm{E} 150)$ & Progen \\
\hline Cingulin & $\mathrm{mAb}, \mathrm{m}(139.3 .4)$. & Progen \\
\hline \multicolumn{3}{|c|}{ Intermediate filaments } \\
\hline \multirow[t]{2}{*}{ Vimentin } & a) $\mathrm{mAb}, \mathrm{m}(3 \mathrm{~B} 4)$ & Progen \\
\hline & b) $\mathrm{AS}, \mathrm{gp}$ & Progen \\
\hline Pan-cytokeratin & $\mathrm{mAb}(\mathrm{Lu}-5), \mathrm{m}$ & Dianova, Hamburg, Germany \\
\hline Cytokeratin 18 & $\mathrm{mAb}, \mathrm{m}(174.1)$ & Progen \\
\hline Cytokeratin 19 & $\mathrm{mAb}, \mathrm{m}(105.6)$ & Progen \\
\hline
\end{tabular}


Table 1 (continued)

\begin{tabular}{lll}
\hline Antigen & Antibody type & Source (reference) \\
\hline Glial fibrillary protein & mAb, m (GF12.24) & Roche Diagnostics, Mannheim, Germany \\
Nestin & $\mathrm{mAb}, \mathrm{m}$ & Santa Cruz Biotechnology \\
Desmin & $\mathrm{mAb}, \mathrm{m}$ & DAKO, Hamburg, Germany \\
Others & & \\
Syndecan-1 & $\mathrm{a}) \mathrm{As}, \mathrm{rb}$ & Zymed \\
& $\mathrm{b}) \mathrm{mAb}, \mathrm{m}(\mathrm{BB} 4)$ & RDI/Chemicon International, Hofheim, Germany \\
Syndecan-2 & $\mathrm{As}, \mathrm{rb}$ & Zymed \\
Syndecan-3 & $\mathrm{As}, \mathrm{rb}$ & Zymed \\
Syndecan-4 & $\mathrm{As}, \mathrm{rb}$ & Zymed \\
Drebrin & $\mathrm{mAb}, \mathrm{m}(\mathrm{clone}$ M2F6) & MoBiTec, Göttingen, Germany \\
Ezrin & $\mathrm{mAb}, \mathrm{m}$ & Sigma \\
Merlin/NF2 & $\mathrm{As}, \mathrm{rb}$ & Santa Cruz Biotechnology \\
Moesin & $\mathrm{mAb}, \mathrm{m}$ & Transduction Laboratories \\
Myosin & $\mathrm{As}, \mathrm{rb}$ & Biotrend, Köln, Germany \\
Actin & $\mathrm{mAb}, \mathrm{m}(\mathrm{AC} 40)$ & Sigma \\
Smooth muscle $\alpha$-actin & $\mathrm{mAb}, \mathrm{m}$ & Progen \\
Cardiac/embryonic $\alpha$-actin & $\mathrm{mAb}, \mathrm{m}$ & Progen \\
\hline
\end{tabular}

\section{Introduction}

During embryogenesis, the developmental programs leading to higher forms of organization involve specific cell segregation and association reactions ("sorting"), resulting in semi-stable cell assemblies and later in the formation of architecturally and functionally defined tissues. Such programs of tissue formation are based on processes of cell proliferation and differentiation, together with the homophilic and heterophilic sorting of cells according to their relative adhesive affinities. Key molecules in the establishment and maintenance of such topogenic cell-cell associations include the diverse cell-type-specific members of the transmembrane glycoprotein superfamily of $\mathrm{Ca}^{2+}$-dependent cell adhesion molecules, the cadherins (e.g., Takeichi 1988; Steinberg and McNutt 1999; Tepass et al. 2000; Duguay et al. 2003).

This raises the question as to whether similar cell adhesion molecules and mechanisms are also involved in processes of cell differentiation and tissue regeneration starting from so-called "adult stem cells" (Verfaillie 2002). In this respect, certain bone-marrow-derived or bloodderived cells that are negative for the surface marker CD34 are of special interest as they have been reported to proliferate and differentiate in cell culture as in the body, thereby producing diverse types of differentiated cells and tissues, ranging from adipocytes to certain kinds of epithelial and endothelial cells, to chondroblasts and osteoblasts, or to cardiac, smooth, or skeletal muscle (e.g., Pittenger et al. 1999; Minguell et al. 2001; Orlic et al. 2001; Fukuda 2002; Jiang et al. 2002; LaBarge and Blau 2002; Ortiz et al. 2003). More recently, however, such cells, commonly referred to as "mesenchymal stem cells" (MSCs) or "multipotent adult progenitor cells", have been discussed fervidly and controversially with respect to their presumed potential in regenerative medicine. Controversy has been particularly stimulated by a series of reports that cells, which on transplantation appear differentiated and integrated into a certain tissue, might result from cell fusion processes or simply reflect the activation of previously cryptic resident cells (e.g., Terada et al. 2002; Ying et al. 2002; Alvarez-Dolado et al. 2003; Spees et al. 2003; Urbanek et al. 2003; Vassilopoulos et al. 2003; Wang et al. 2003).

In view of the ongoing heated discussion regarding the nature and post-transplantation fate of these bone-marrowderived MSCs, it is surprising to note the paucity of cell biological knowledge that still exists in this field. In our studies of cultured MSCs, we have recently noted that such cells are interconnected by an elaborate system of special adhering junctions located on the main cell body and on cell processes of variable lengths, including some extremely long processes that form small punctate junctional contacts with one or several cells in the vicinity and over remarkable distances, or are deeply inserted in a tight-fitting manner into special invaginations, thus forming extended adherent interlocks.

\section{Materials and methods}

\section{Cell cultures}

For the preparation of human MSCs, aspirates from bone marrow donated by several young (25-35 years) volunteers were used to isolate mononuclear cells by Ficoll density 
gradient centrifugation (for approval by the Heidelberg University Ethical Board, see Wagner et al. 2005). The cell fraction growing in a substrate-adherent manner in "MSC growth medium" (Osiris Therapeutics, Baltimore, Md., USA) essentially as described by Pittenger et al. (1999) was used. A panel of twelve antibodies was routinely applied to examine the phenotype of these cells (negative: CD34, -38, -45, and HLA-DR; positive: CD13, -29, -44, -73,
$-90,-105,-106$, and -166$)$, and the cells were characterized, for example, by their ability to differentiate into colonies positive for markers indicative of adipogenic, chondrogenic, osteogenic, or myogenic differentiation (cf. Jiang et al. 2002). For biochemical experiments, cells were usually grown in 120-ml culture flasks to variable densities, whereas for light and electron microscopy, they were mostly grown on normal glass coverslips or on Permanox Chamberslides

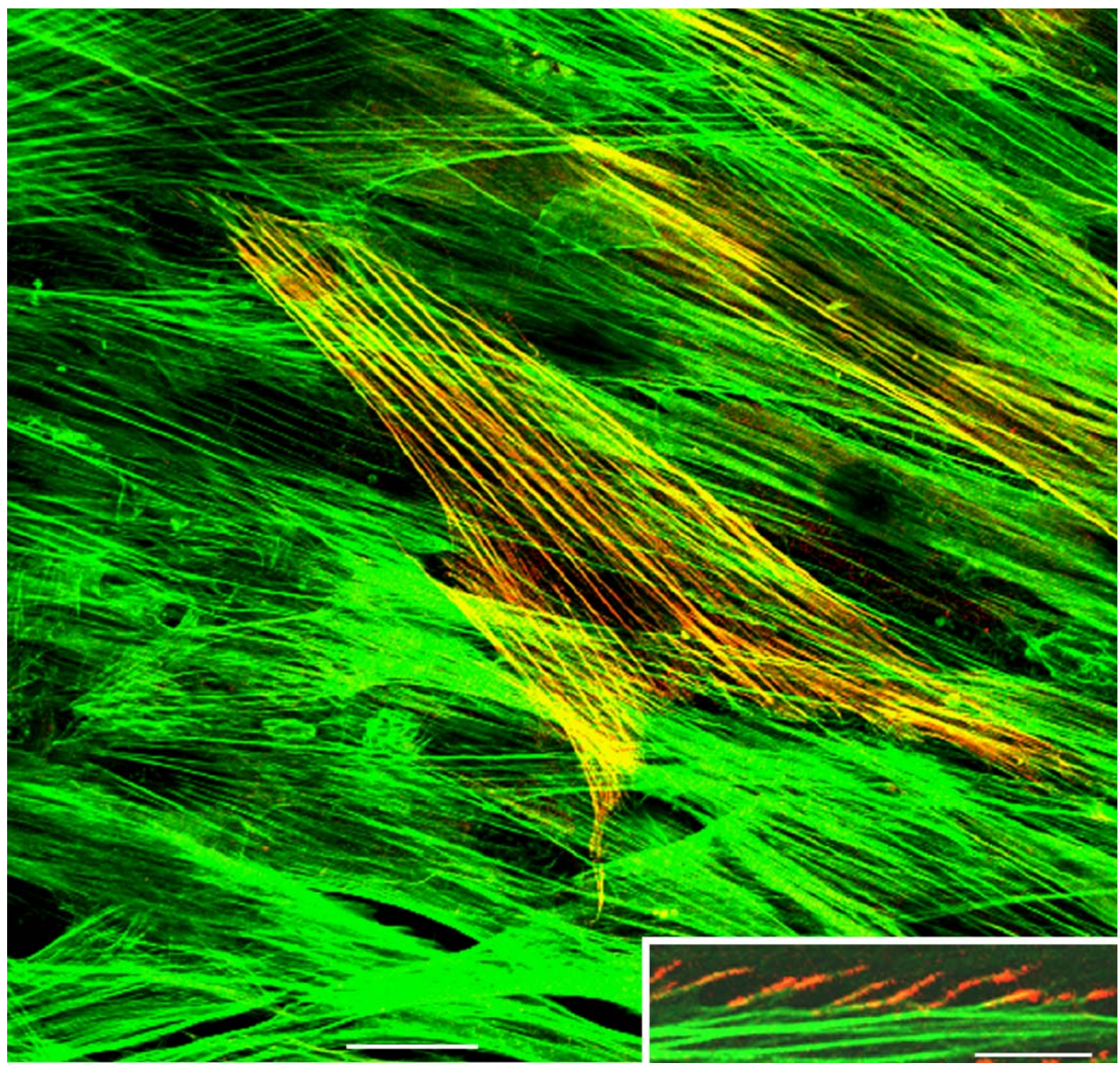

Fig. 1 Immunofluorescence microscopy of a densely grown monolayer culture of human mesenchymal stem cells (MSCs) derived from bone marrow, showing cytoskeletal heterogeneity. All cells contained numerous bundles of actin microfilamenbts (green, stained with fluorescently labeled phalloidin) but a minor proportion of the cells also reacted with antibodies specific for smooth muscle $\alpha$-actin (red, appearing here mostly in yellow (merge image). Insert (lower right):
Cell-cell junction bridges between an MSC with bundles of microfilaments containing smooth muscle-type $\alpha$-actin (green, immunostaining) and an MSC with non-muscle-type actin filament bundles (dark) that are interconnected by numerous bridges, the cytoskeletal elements of which have been visualized by immunostaining with antibodies against $\beta$-catenin (red). Bars $20 \mu \mathrm{m}$ (survey), $10 \mu \mathrm{m}$ (insert) 
(Nalge Nunc, Naperville, Ill., USA) and processed as described (Peitsch et al. 2001; Langbein et al. 2002). Alternatively, equivalent cultures were prepared from umbilical cord blood by using similar methods (cf. Bieback et al. 2004).

Human venous endothelial cells prepared from umbilical cords and grown in culture (cf. Peitsch et al. 2001) were used for comparison, as were cells of the human lines U333 (astrocytoma), CaCo-2 (colon adenocarcinoma), MCF-7 (mammary adenocarcinoma), PLC (primary hepatocellular carcinoma), HaCaT (keratinocytes), and SV80-fibroblasts (from ATCC, Manassas, Va., USA, or as specified by Peitsch et al. 2001; Langbein et al. 2002).

\section{Antibodies}

The antibodies used and their sources are listed in Table 1.

\section{Light and electron microscopy}

Protocols used for conventional light and electron microscopy and for immunolocalization experiments at both levels were as previously described (Peitsch et al. 2001; Langbein et al. 2002).

\section{Biochemical experiments}

The preparations of cell lysates or cytoskeletal fractions from MSCs, the procedures for particle and protein fractionation, the immunoprecipitation protocols, and the methods used for protein identification were as described (e.g., Peitsch et al. 2001; Langbein et al. 2002).

\section{Results}

Once we had noted that human MSCs obtained from bone marrow aspirates or umbilical cord blood and grown in culture for several passages were regularly interconnected by numerous adhering junctions of the puncta adhaerentia category, including many located on cell-to-cell bridges of various lengths, we decided to characterize their molecular composition. In general, at this time of culturing, the MSCs

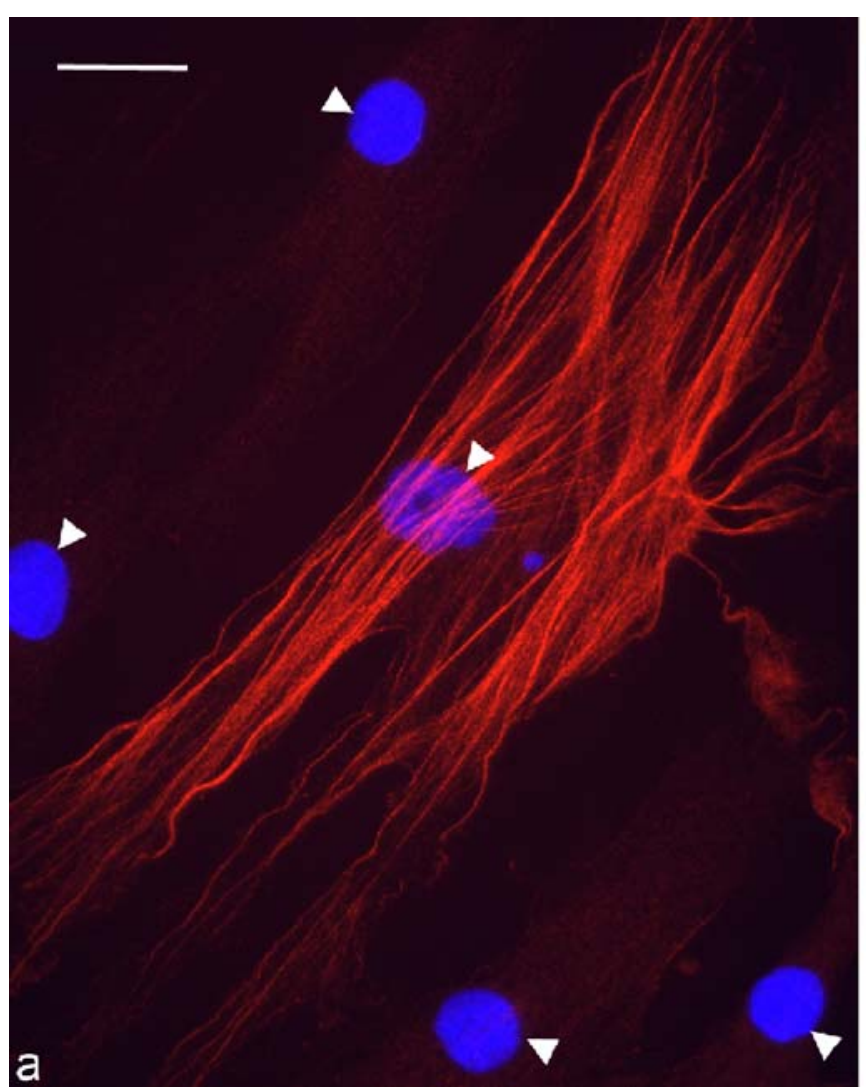

Fig. 2 Double-label immunofluorescence microscopy of an MSC culture grown to high density, showing some cells rich in axially oriented microfilament bundles. Note that, in $\mathbf{a}, \mathbf{b}$, two of the cells contain bundles of microfilaments positive for cardiac $\alpha$-actin (red; antibody mAb 20.4.2; for details and modifications of the immuno-

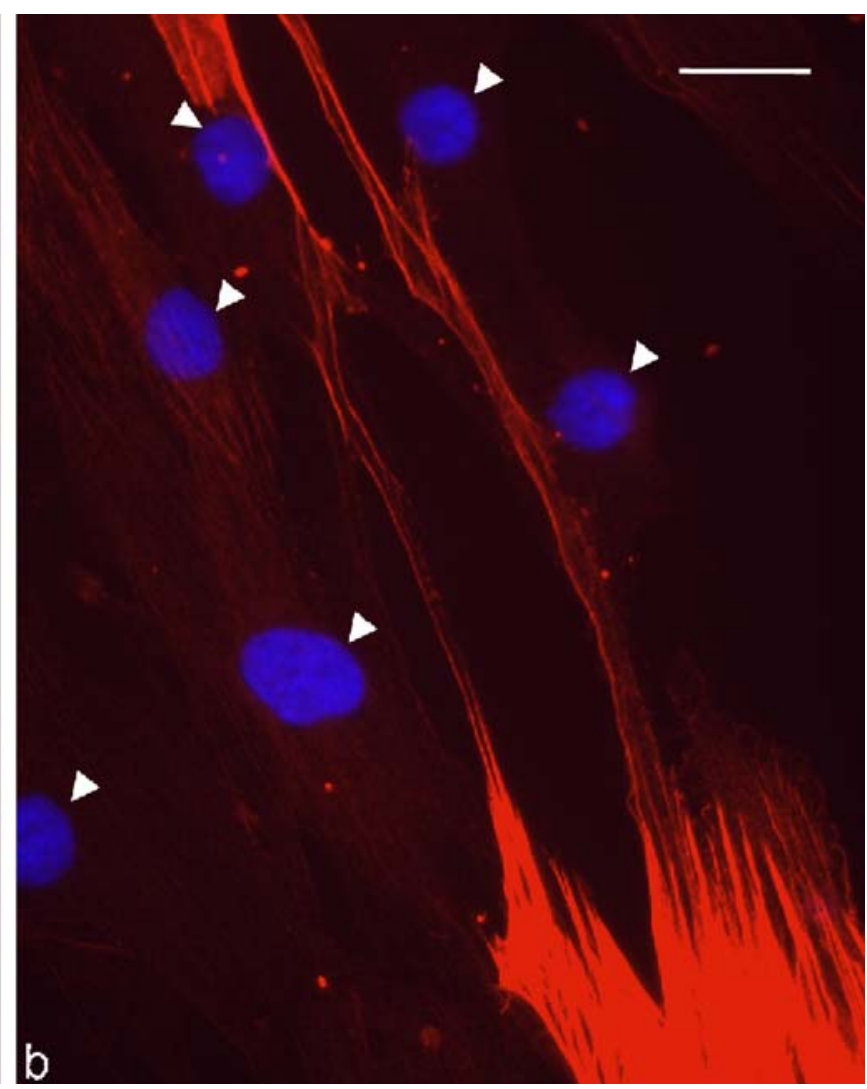

localization protocol, see Moll et al. 2006); these are not only dominant in the central cytoplasm (a) but also extend into the long thin cell processes (b); the processes shown here exceed $100 \mu \mathrm{m}$ in length. Cell nuclei are stained with 4,6-diamidino-2-phenylindole (DAPI; arrowheads). Bars $10 \mu \mathrm{m}$ 
were similar in shape, and all cells were rich in actin microfilament bundles and intermediate-sized filaments (IFs) containing vimentin. On closer inspection, however, some heterogeneity in gene expression and differences in the synthesis of cytoskeletal and other major proteins could not be overlooked.

\section{Cytoskeletal heterogeneity of MSCs}

Although, in the literature, MSCs are commonly seen as a uniform population of fibroblastoid cells, we had noted the occurrence of MSC colonies (at variable frequencies) with different cytoskeletal proteins, indicative of the formation of subtypes differing in cell differentiation. With remarkable consistency, we observed MSCs that were characterized by bundles of microfilaments containing the smooth-musclecharacteristic form of $\alpha$-actin, in addition to the dominant non-muscle forms of $\beta$ - and $\gamma$-actin (Fig. 1), in agreement with a recent report of Kinner et al. (2002). On the other hand, we were also able to identify MSCs that exhibited widely differing morphology and that were positive for filaments containing the cardiac and embryonic type of $\alpha$ actin (Fig. 2a); such cardiac $\alpha$-actin-containing filaments extended even into the thinnest cell processes (Fig. 2b). However, the patterns of cytokeratin synthesis in the MSCs that were rich in IFs of the vimentin type were
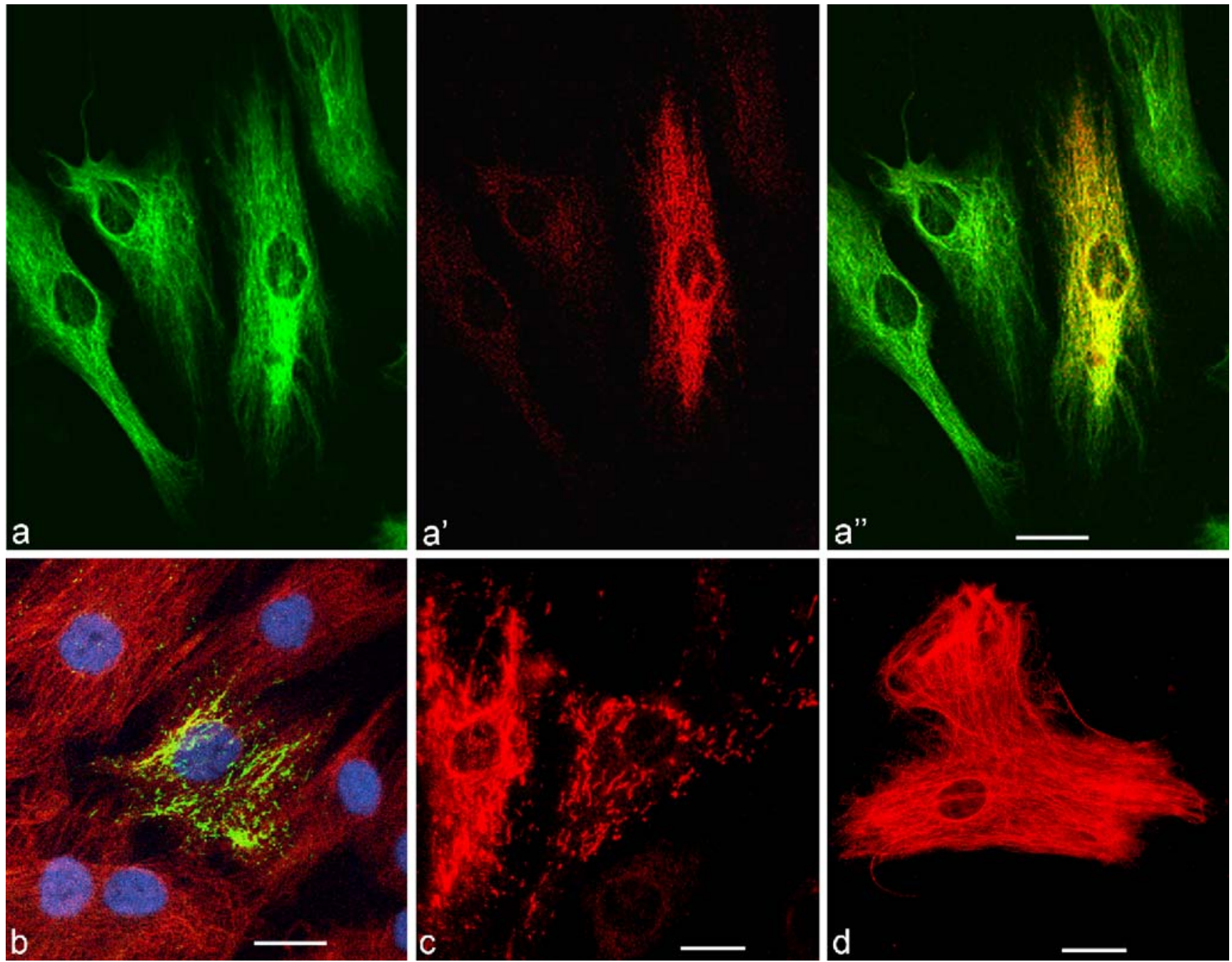

Fig. 3 Immunofluorescence microscopy of an MSC culture, showing intermediate-sized filament (IF) bundles containing cytokeratins in a small proportion of the cells. a-a" Cells immunostained for vimentin (green, a) and cytokeratin 19 (red, a'; mAb Z105) show the occurrence of both IF systems (a", yellow, merge image). b Whereas all MSCs contain extended vimentin filament bundles (red, immunostaining), some cells are also positive for certain cytokeratins that partly appear in small granular aggregates and short filamentous arrays (green, cytokeratin mAb Lu-5). c Cytokeratin filament aggregates and structures of various sizes and complexity visualized by reaction with mAb Lu-5 in two of the cells present. d In an MSC culture, two adjacent cells contain IFs positive for cytokeratin 18 (mAb 174.1). Bars $20 \mu \mathrm{m}$ 


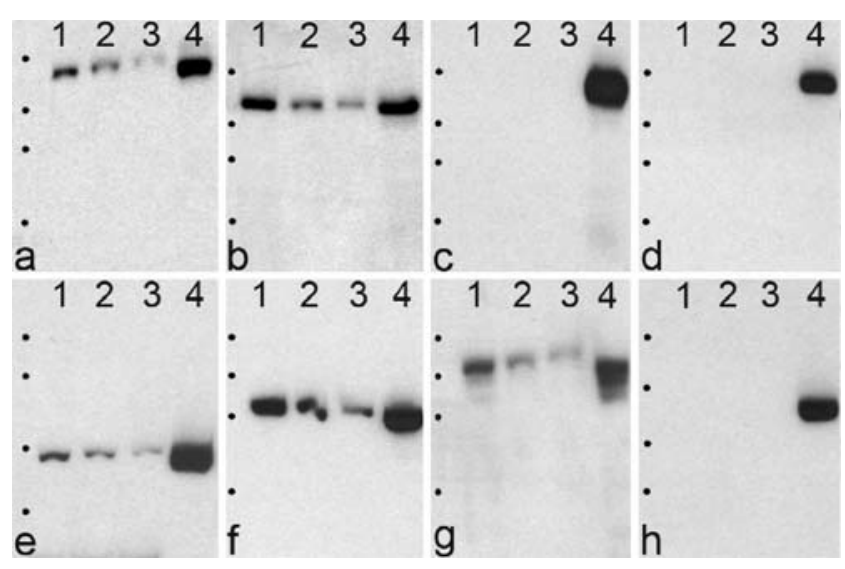

Fig. 4 Biochemical characterization of cytoskeletal and junctional proteins present in total extracts from human cultured MSCs. MSCs from human bone marrow samples from three different patients were grown for 7 days as substrate-adherent monolayers: MSC 209 (lane 1), MSC 185 (lane 2) and MSC 179 (lane 3) were compared with human glioma cells of line U333 (lane 4 in $\mathbf{a}, \mathbf{b}$ ) and HaCaT keratinocytes (lane 4 in $\mathbf{c}-\mathbf{h}$ ). Proteins separated by SDS-polyacrylamide gel electrophoresis were immunoblotted with antibodies specific for the following proteins: a $\mathrm{N}$-cadherin (note positive reactions in all lanes); b cadherin-11 (positive reactions in all lanes); $\mathbf{c}$ E-cadherin (note absence of reaction with MSCs but positive reaction in lane 4); $\mathbf{d}$ desmoglein Dsg 2 (note exclusive reaction in HaCaT cells, lane 4); e $\alpha$-catenin (positive reactions in all cell lines examined); $\mathbf{f} \beta$-catenin (positive reactions in all cell lines examined); g p120 (positive reactions in all cell lines examined); $\mathbf{h}$ plakophilin 2 reacts exclusively with the $\mathrm{HaCaT}$ cells (lane 4). Positions of molecular weight references are shown by dots (left; in $\mathrm{kDa}$ from top to bottom: 158, 116, 97.2, 66.4) particularly heterogeneous (see Fig. 3a-d for various examples of small and larger filament aggregates and bundles formed by cytokeratins, including cytokeratins 18 and 19). Similar heterogeneities were also found in sections through processes of mesenchymal tissue, notably bone marrow.

Apparently, some of the cells with additional marker proteins were able to proliferate into small MSC colonies. However, the appearance of certain cell differentiation markers in a given cell or group of cells did not necessarily mean that these cells had embarked on a separate differentiation pathway, as long as the specific larger differentiation-specific ensemble of proteins and structures was not present. For example, we normally did not note the advent of true desmosomes in cytokeratinpositive cells, the typical cardiac myosins and intercalated disk proteins in the cells positive for cardiac $\alpha$-actin, or the presence of desmin filaments in cells containing smoothmuscle-type $\alpha$-actin. Therefore, we regarded these syntheses of certain cytoskeletal proteins and their assembly to filamentous structures as being representative of subclasses of cells and cell clones characterized by the loss of control of gene expression (e.g., Knapp and Franke 1989) and not as being evidence for the heterogeneity of cell differentiation and fate.
Fig. 5 Immunofluorescence micrographs showing the coupling and interaction of MSCs in interphase and mitosis, as revealed by $\beta$-catenin immunostaining of their adhering junctions. MSCs are connected by numerous, variously sized, bridge-like and interdigitating structures containing adhering junctions (a) that (b) are reduced in number and average length during mitosis. Bars $50 \mu \mathrm{m}$
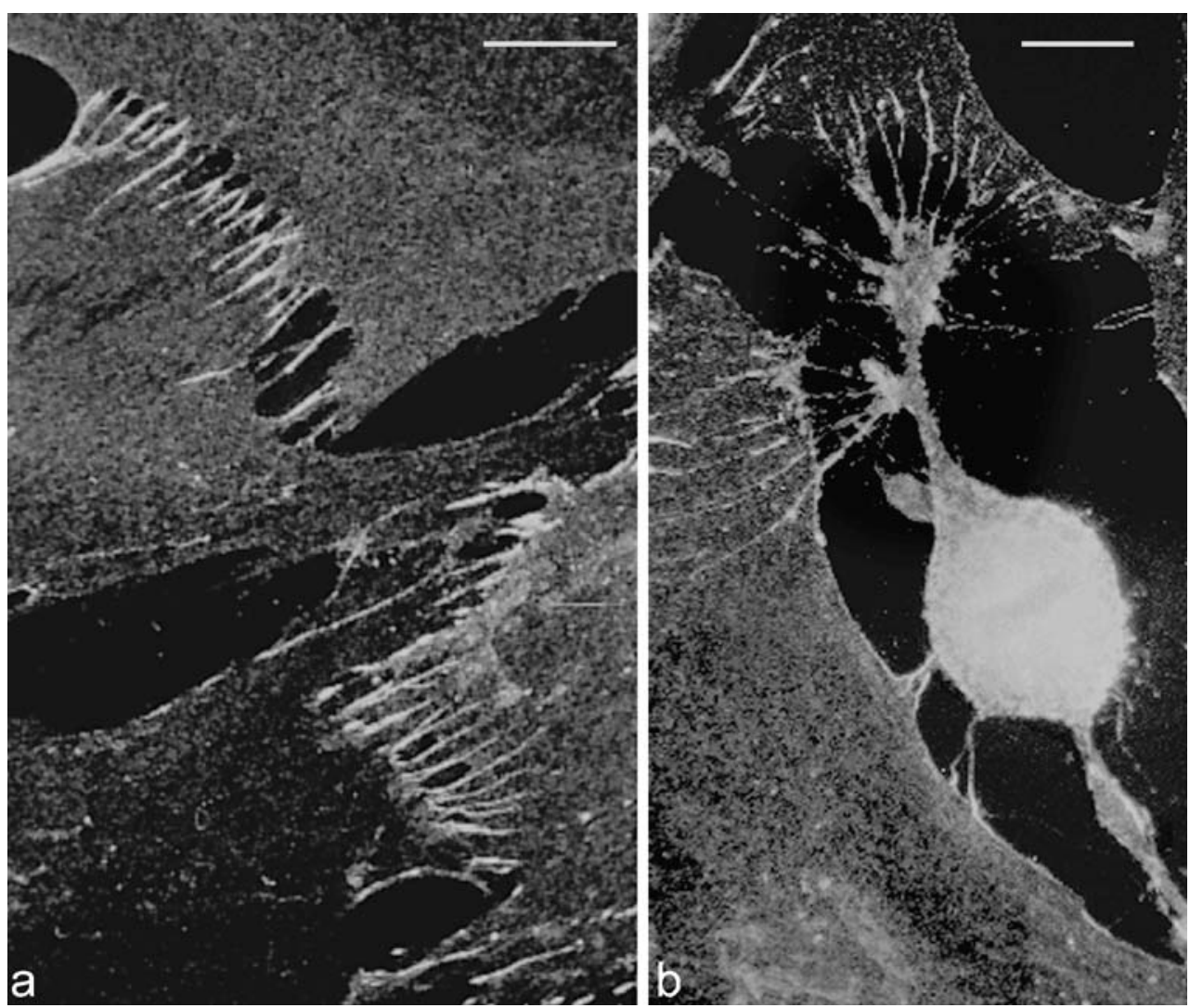

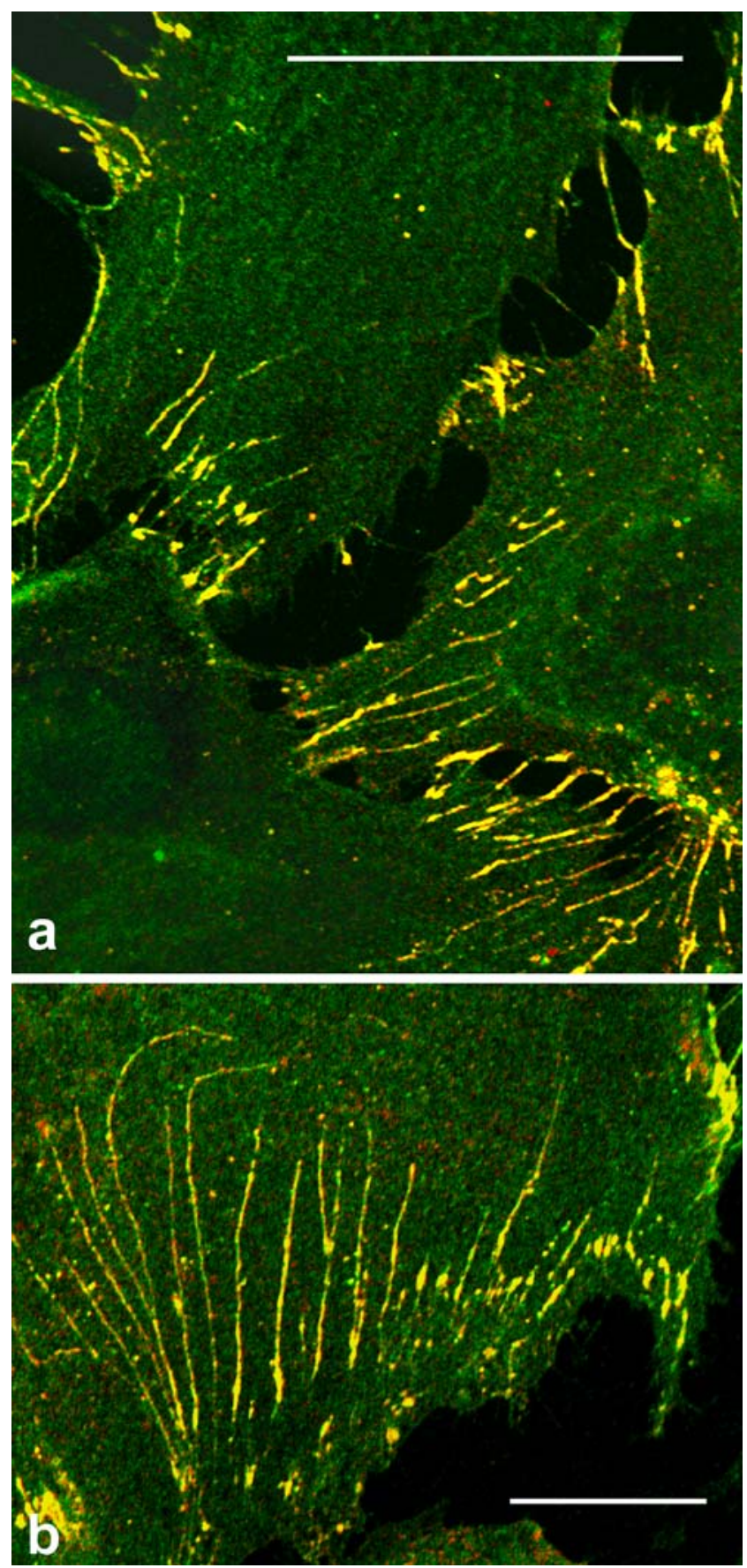

Fig. 6 Double-label immunofluorescence confocal laser scanning microscopy, showing two adjacent MSCs connected by processus adhaerentes of various lengths; many insert in a tight-fitting manner into invaginations of adjacent cells and appear to form continuously immunostained interlocking rod structures. Only the merge images are presented; the junctional structures appear yellow as they are positive for both $\mathrm{N}$-cadherin (red) and $\alpha$-catenin (green). The same structures are also positive for cadherin-11, $\beta$-catenin, and protein p120. Bars $50 \mu \mathrm{m}(\mathbf{a}), 20 \mu \mathrm{m}$ (b)

\section{Biochemical analysis of junctional proteins}

When proteins of total MSCs or of the cytoskeletal fractions containing IFs and junctions were analyzed by gel electro- phoresis and immunoblotting, the transmembrane proteins $\mathrm{N}$-cadherin and cadherin-11 (OB-cadherin 1) were consistently found (results from three different cultures are shown in Fig. 4a,b). In some analyses, the glycosyl-phosphatidylinositol-anchored protein T-cadherin also showed a positive but weak reaction (not shown). Other cadherins examined, such as E-, M-, P-, R-, and VE-cadherin, cadherins 6 and 8, and LI-cadherin, and the desmosomal cadherins, desmogleins (Dsg1-3) and desmocollins (Dsc1-3), were not detected (e.g., Fig. 4c,d). Correspondingly, we observed typical adhering junction plaque proteins, such as $\alpha$ - and $\beta$-catenin (Fig. 4e,f), the actin-filament-anchoring $\alpha$-catenin-related protein vinculin (not shown), and the $\beta$ catenin-related armadillo-type protein $\mathrm{p} 120^{\mathrm{ctn}}$ (Fig. $4 \mathrm{~g}$ ). Plakoglobin, an armadillo protein that can occur in both adhering junctions and desmosomes, was detected only in minor amounts (not shown), and a similar result was obtained for protein $\mathrm{ZO}-1$, a protein known to occur in the cytoplasmic plaques of adhering and of tight and gap junctions. We did not detect any of the desmosome-typical plaque proteins, i.e., desmoplakins I and II or plakophilins PKP1-3 (for PKP2 see Fig. 4h). Of the nectin-afadin-ponsin group of junctional proteins (for a review, see Takai and Nakanishi 2003), afadin was regularly identified (see below). We also found relatively large amounts of actin-binding proteins, including ezrin, moesin, $\alpha$-actinin, and myosin (not shown; see below), but only small amounts of drebrin. None of the tight-junctional transmembrane proteins was detected. In initial experiments, we also observed positive reactions with an antibody against syndecan-1; however, in careful controls, this turned out to be attributable to a (cross-)reaction of the specific antibodies with $\beta$-catenin (not shown).

When we examined the interactions between the junctional proteins by immunoprecipitation experiments, primarily by using antibodies specific for N-cadherin or cadherin-11, followed by SDS-polyacrylamide gel electrophoresis and immunoblotting, we noted co-immunoprecipitations of Ncadherin with the plaque proteins $\alpha$ - and $\beta$-catenin and protein $\mathrm{p} 120^{\mathrm{cth}}$. These precipitates also contained the actinbinding proteins, ezrin and vinculin (not shown). Correspondingly, cadherin-11 co-immunoprecipitated $\alpha$ - and $\beta$-catenin and $\mathrm{p} 120^{\mathrm{ctn}}$, together with minor amounts of vinculin, but not $\mathrm{N}$-cadherin.

\section{Immunolocalization of adhering junctional proteins}

Various markers of adhering junctions localized not only to the small puncta adhaerentia on the main cell bodies and on the bridge-like intercellular connections of various lengths, but also surprisingly to those on the abundant long cell processes (processus adhaerentes), some of which were deeply inserted into recesses (recessus adhaerentes) in the specific partner cell. Examples showing the localization of the 

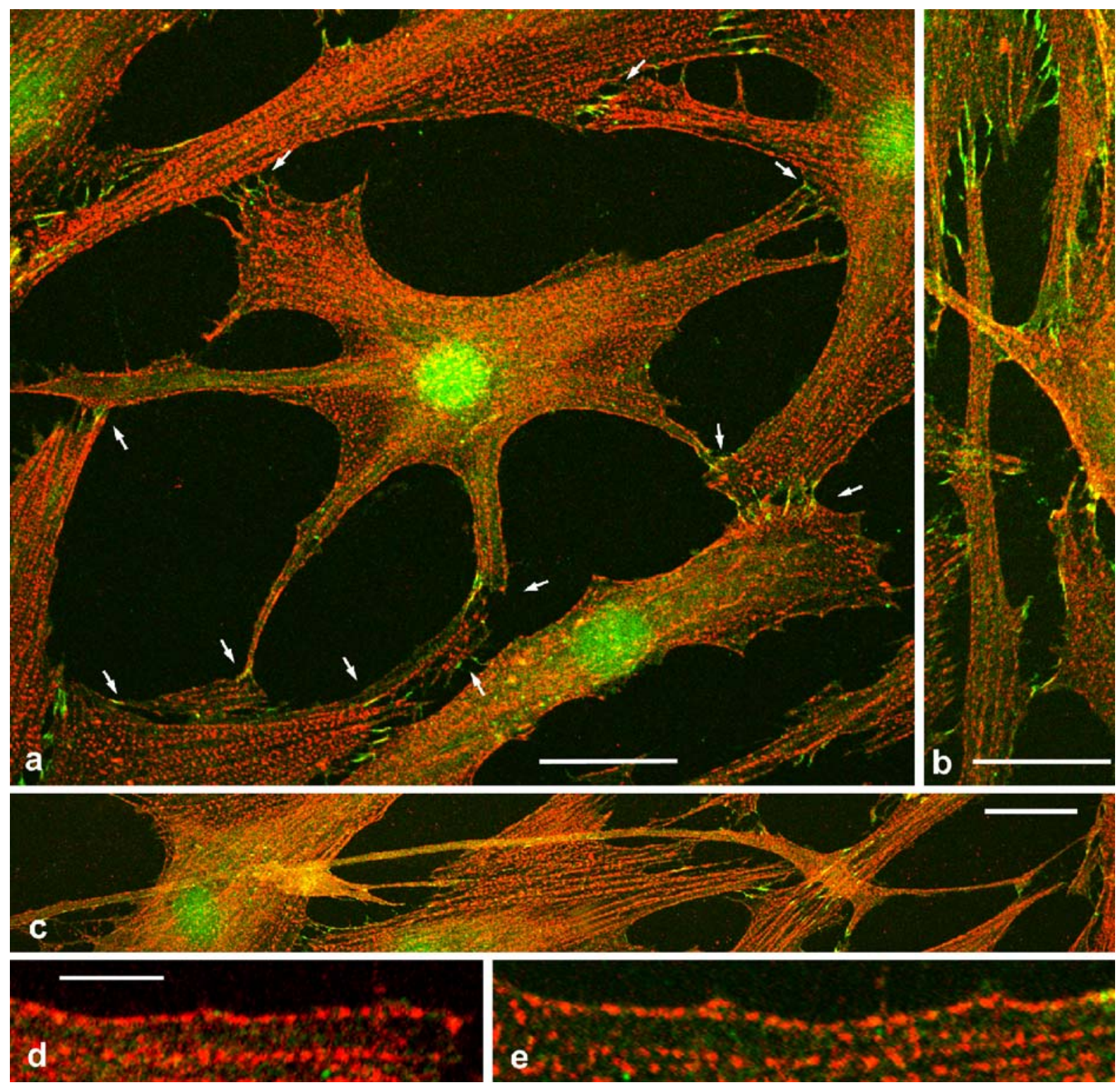

Fig. 7 Double-label immunofluorescence laser scanning micrographs of an MSC culture illustrating the frequency of $\alpha$-actinin-rich dense bodies and of the variously sized cell processes forming cell-cell contacts. The actin-binding protein, $\alpha$-actinin ( $r e d$, murine $\mathrm{mAb}$ ), is enriched in dense bodies that are periodically arranged along actin microfilament bundles, whereas $\beta$-catenin (green, rabbit antibodies) is concentrated in the nuclei and the cell-cell adhering junctions (some being denoted by short arrows in a). Note that the central MSC in a is

plaque proteins $\alpha$ - and $\beta$-catenin, in combination with $\mathrm{N}$ cadherin, are presented in Figs. 5, 6. All the adhering junctional proteins identified were mostly biochemically colocalized (e.g. Fig. 6), including proteins $\mathrm{p} 120^{\mathrm{ctn}}$ and afadin (not shown) as well as plakoglobin and protein ZO-1, although the latter reactions were much weaker.

In sparse or subconfluent cultures, many of the cell processes were characterized by punctate or extended sites of colocalization of the adhering junctional proteins mentioned (Figs. 7, 8). The processus adhaerentes often connected by seven processes to five other cells and that the single cell process shown in $\mathbf{b}$ forms junction contacts with five other cells in the region shown here. A remarkably long $(>300 \mu \mathrm{m})$ process connected by adhering junctions to a number of other cells extends across $\mathbf{c}$ (left to right). d, e Typical regular arrays of $\alpha$-actinin-rich dense bodies at higher magnification (mean center-to-center distances ranging between 0.7 and $1.2 \mu \mathrm{m})$. Bars $25 \mu \mathrm{m}(\mathbf{a}-\mathbf{c}), 5 \mu \mathrm{m}(\mathbf{d}, \mathbf{e})$

reached lengths of up to several hundred micrometers and formed either cell-cell bridges with similar processes or with the main bodies of other cells or were inserted in a tight-fitting manner into the deep recesses of adjacent cells, often resulting in batteries of almost parallel arrays of long adherent interlocks representing tube-like junctional arrays with a continuous appearance (manubria adhaerentia; Fig. 6). Such processes were also seen to connect mitotic cells with neighboring interphase cells, although the number of bridge connections seemed to 
Fig. 8 Double-label immunofluorescence laser scanning survey micrograph of an MSC culture, presenting an example of a giant processus adhaerens connecting several cells. The extremely long cell process extending from bottom to top exceeds $480 \mu \mathrm{m}$ and forms junctions with at least five other cells. Immunoreaction with antibodies to the actin-binding protein ezrin (red) and $\beta$-catenincontaining puncta adhaerentia (green), often locally resulting in yellow colour (merge image). Bar $100 \mu \mathrm{m}$

be greatly reduced at metaphase-anaphase (e.g., Fig. 5b). In general, the cell bodies and the processes were rich in actin filament bundles and several actin-binding proteins, such as myosin, $\alpha$-actinin (Fig. 7), and ezrin (Fig. 8). The abundance of $\alpha$-actinin was particularly impressive as most of this protein took the form of "dense bodies" periodically arranged along the microfilament bundles (Fig. 7; mean center-to-center spacings ranging between 0.7 and $1.2 \mu \mathrm{m}$, i.e., similar to that in several other cell lines; e.g., Sanger et al. 1983). In addition to actin microfilament bundles such cell processes also contained microtubular structures (Fig. 9).

The high frequency of puncta adhaerentia on the main MSC bodies and on the processus adhaerentes was best demonstrable in samples gently prepared to allow the preservation of these tenuous and fragile structures in large survey double-label immunolocalization micrographs (e.g., Figs. 7, 8, and 9). In optimal preparations, cell processes could be traced and shown to make junctional contacts with a number of other cells (up to 8 were determined), often over distances exceeding $400 \mu \mathrm{m}$ (e.g., Fig. 8).

\section{Electron microscopy}

We succeeded in obtaining electron micrographs of nearlongitudinal sections through processus adhaerentes of remarkable lengths, including some involved in the formation of cell-cell bridges. Some cell-cell contact sites (e.g., Fig. 10a) apparently exhibited "fresh" intercellular adhesion structures that were still without adhering junctions, whereas others (e.g., Fig. 10b) revealed conspicuous junctional associations in the overlapping tip regions of the processes from two different cells ("ET touches"). At higher magnification, such processes showed not only bundle arrays of actin microfilaments and occasional microtubular structures, but also individual (sometimes small: diameters 30-200 nm) puncta adhaerentia (Fig. 10c, arrows). Immunoelectron micrographs allowed us to localize specific junctional proteins to such small punctate junction structures (e.g., Fig. 10d illustrates the antibody decoration of $\beta$-catenin). The variable sizes and configurations and the patterns of the arrangements of such puncta adhaerentia and their spatial relationships to other structures, such as the microfilament bundles and interspersed gap junctions, are shown in Fig. 10e-h.

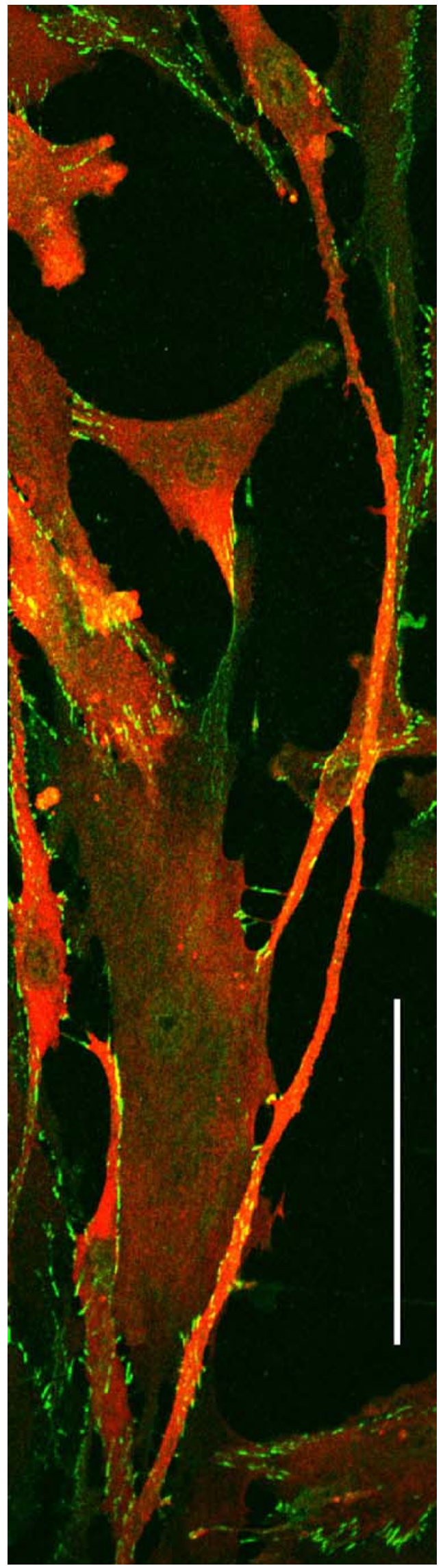




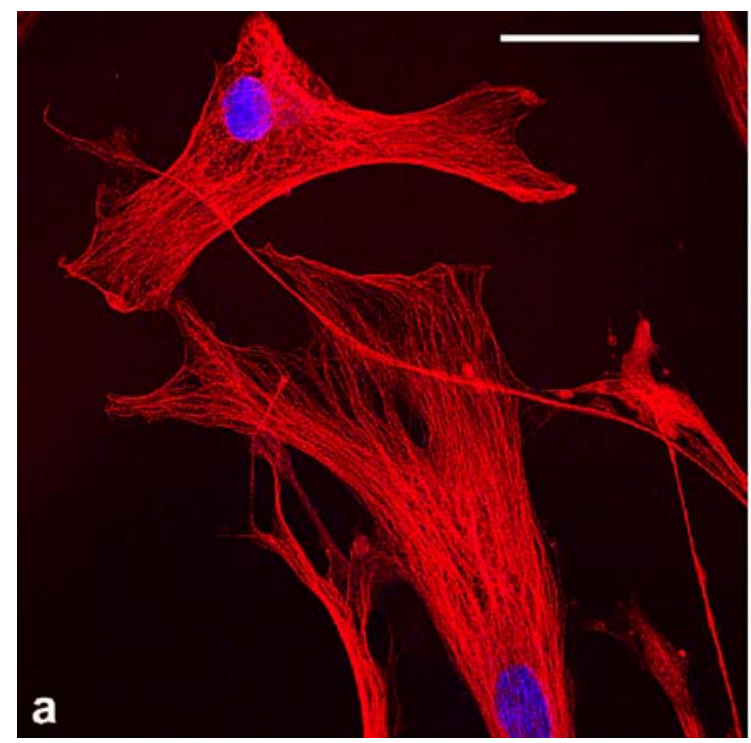

Fig. 9 Immunofluorescence microscopy with antibodies to $\alpha$-tubulin, demonstrating the general occurrence of microtubules in human MSCs, irrespective of specific cell morphology, including thin and long processes. a Survey picture of a sparse culture showing a long

Other slender cell processes, also containing cores of actin microfilament bundles, were traced protruding into and inserted tightly into deep plasma membrane recessus adhaerentes (Fig. 10i,j) in which the individual adhering junctions mostly appeared "fused" into the continuous membrane-to-membrane associations of the manubria adhaerentia, forming long attachment cuffs, the obvious equivalents of the long junctional structures that, by immunofluorescence microscopy, appeared as extended regions of the colocalization of adhering junction markers (e.g. Fig. 6).

\section{Alterations with increasing cell density}

The cell processes, whether extending through the intercellular space or included in adherent interlocking manubria, were highly dynamic and changed their morphology drastically within relatively short periods of time. A detailed analysis of such morphological changes is currently underway and will be presented elsewhere. Following cell proliferation and growth in these cultures, we noted highly dynamic foreshortening and reorganization of the cell processes and recesses, especially when maximal cell package density in monolayer cultures was approached (Fig. 11a). These cells were still connected by a large number of cell-junction bridges, which were however much shorter (Fig. 11b).

\section{Discussion}

The adhering junction-bearing cell processes shown here are remarkable structures, not only for mesenchymal cells,

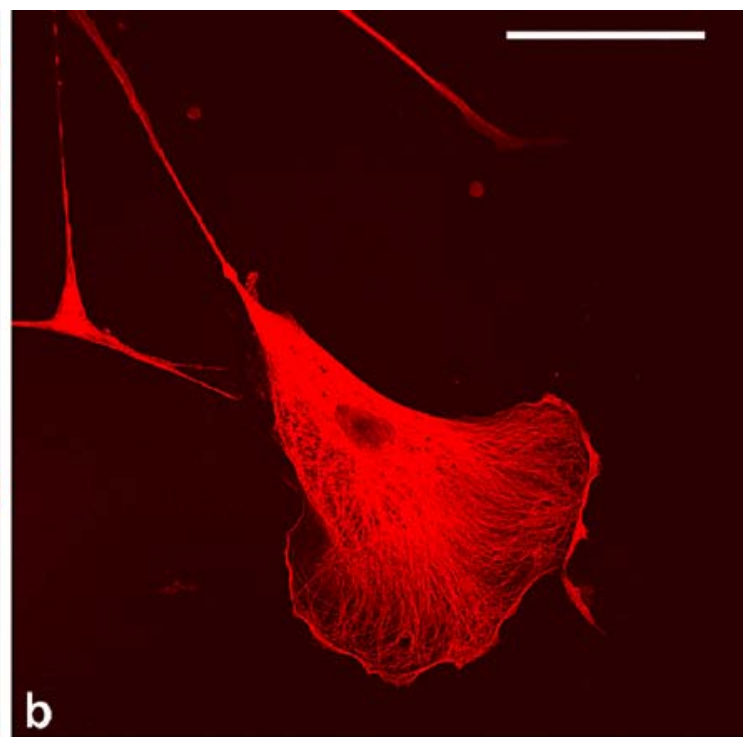

slender process of more than $200 \mu \mathrm{m}$, running top left to bottom right). b Typical polar fibroblastoid cell with a broad lamellipodium and a long posterior process. Bars $50 \mu \mathrm{m}$

but generally in cell biology. They vary greatly in size, with some reaching enormous lengths of up to $0.5 \mathrm{~mm}$ and ranking second only to the special processes of neuronal cells, i.e., neurites. Their cytoskeletal core is essentially based on a system of actin microfilament bundles, fortified and attached to the cell membrane via myosin, $\alpha$-actinin, ezrin, and probably other morphogenic actin-binding proteins that have yet to be identified (for candidates see, e.g., Bonilha et al. 1999; Vaheri et al. 1997; Bretscher et al. 2002; Kobielak et al. 2004) and of microtubules (cf. Fig. 9). Remarkably, such long processes have also been seen on cells containing additional differentiation-specific proteins such as smooth or cardiac muscle $\alpha$-actins or diverse cytokeratins. In this context, a specific type of interstitial cell with two or three long (up to $30 \mu \mathrm{m}$ ) thin cell processes has recently been identified in human atrial myocardium (Hinescu et al. 2006).

The plaque-bearing puncta adhaerentia junctions on these "free" cell processes, a system resembling suckers on the tentacles of an octopus, are mostly small but, in certain places, seem to be able to fuse laterally to form larger adhesive junctions. Indeed, only a few of these junctions are sufficient to form stable bridges ("ET touches") in the intercellular space, often at remarkable distances from the main cell bodies. The molecular composition of these junctions is simple. Apparently, the coexistence of $\mathrm{N}$-cadherin and cadherin- 11 is typical for puncta adhaerentia of diverse mesenchymal cells and tissues (e.g., Okazaki et al. 1994; Hoffmann and Balling 1995; Kimura et al. 1995; Simonneau and Thiery 1998; Hinz et al. 2004), as are cytoplasmic plaques comprising $\alpha$ - and $\beta$ catenin, together with protein p120 and afadin, whereas 
appreciable amounts of other plaque proteins seem to be lacking (for references, see Straub et al. 2003; Godsel et al. 2004; Irie et al. 2004; for a possible role of gelsolin in the anchorage of the actin filaments at adhering junctions of fibroblasts and probably also other mesenchymally derived cells, see Chan et al. 2004). The functional importance of the molecular complement of these puncta adhaerentia in the differentiation of mesenchymal cells and tissue formation is indicated by the developmental defects described for mice lacking N-cadherin or cadherin-11 or both (Radice et al. 1997; Horikawa et al. 1999; Luo et al. 2004; Kostetskii et al. 2005) and by the general importance of cadherin-11 in the regulation of cell motility and cell-cell interaction in the dynamics of mesenchymal cells (cf. Kiener et al. 2006, and refs. therein).

A subtype of such cell processes can insert, in a tightly fitting manner, into deep surface membrane recesses of recipient cells, thus forming particularly stable, often cufflike, cell-cell interlocking junctions, which are mostly fused to form large continuous manchette-like interlocking arrangements termed manubria adhaerentia (Fig. 12). Indeed, such manubria can be generally regarded as single but large adhering junctions, occupying cell surface areas up to $100 \mathrm{\mu m}^{2}$; hence, the total cell-cell adhesive surface can exceed $10^{3} \mu \mathrm{m}^{2}$. Clearly, these interdigitating batterylike arrays of manubria profoundly differ from the much shorter E-cadherin-based cell processes, sparsely set with puncta adhaerentia, as described in the filopodial "zippers" of keratinocyte cultures (Vasioukhin et al. 2000) and from the E-cadherin-based tight-fitting cell-to-cell structures of spreading Listeria monocytogenes (Cossart and Lecuit 1998; Hamon et al. 2006).

The abundance of ezrin in the processus adherentes of MSCs is remarkable in several ways. Although this protein originally and typically has been reported in microvilli and other organized protrusions of epithelial cells, it has subsequently also been identified in cell extensions of diverse types of mesenchymal cells (for reviews, see Vaheri et al. 1997; Bretscher et al. 2002). Moreover, whereas its roles as a potentially actin-binding and actin microfilamentto-membrane linking protein and as an adhering junctionassociated protein have been demonstrated in many examples, it has more recently also been reported to act as a signaling and life-protecting protein (e.g., Gautreau et al. 1999; Bretscher et al. 2002; and references cited therein) and may be more generally involved in morphogenic processes, probably tightly controlled by kinase activities (Bonilha et al. 1999; Lan et al. 2006). Clearly, our finding of ezrin as a major cytoskeletal component in MSC processes should now lead to investigations regarding its presence and fuction in the formation of processes of mesenchymal cells during early embryogenesis or in adhering junction-stabilized cytoplasmic projections of retothelial cells of the sinus of lymph nodes (cf. Hämmerling et al. 2006).
Fig. 10 Electron microscopy of ultrathin sections through processus adhaerentes forming intercellular bridges $(\mathbf{a}-\mathbf{h})$ or deeply rooted manubria adhaerentia (i, j). a Tentacle-like process (left) making contact (bracket) with another MSC, but a plaque junction structure cannot yet be recognized at the contact site. b Survey picture showing two long thin processes contacting each other at a small overlapping contact region ("ET touch", denoted by bracket). c Partial magnification of the contact region demarcated in $\mathbf{b}$, showing the actin microfilament bundles of the core of the process and a series of closely spaced small puncta adhaerentia characterized by a dense cytoplasmic plaque (arrows). d Immunoelectron micrograph presenting a similar overlapping contact region as shown in $\mathbf{b}, \mathbf{c}$ after specific reaction of $\beta$-catenin antibodies as detected by the immunogold procedure with silver enhancement. Note the exclusive localization of reaction product at the junctional plaques (arrowheads). e A different complex form of MSC contact with a single and slightly larger junction anchoring an actin filament bundle (arrow). f Another morphotype of MSC contact formed by a battery of small adhering junctions (arrowheads). g Typical array of small nascent puncta adhaerentia (arrowheads) and their lateral attachment to a cable of actin microfilaments (denoted by brackets). h Similar group of adhering junctions (arrowheads) as in the previous figures, interspersed with a gap junction (arrow). i, $\mathbf{j}$ Typical aspects of slender cell processes inserted in a tight-fitting manner into corresponding invaginations of adjacent cells. Note the high density of actin microfilaments in these processes and the densely plaque-coated plasma membrane contact regions (arrowheads) forming a nearly continuous adhering junction structure (manubrium adhaerens). Bars $0.2 \mu \mathrm{m}(\mathbf{d}, \mathbf{g}-\mathbf{i}), 0.5 \mu \mathrm{m}(\mathbf{c}, \mathbf{e}, \mathbf{f}, \mathbf{j}), 1.0 \mu \mathrm{m}(\mathbf{a}), 2.0 \mu \mathrm{m}(\mathbf{b})$

The variously sized cell processes, including the extremely long tentacular processes equipped with puncta adhaerentia, appear to provide highly suitable instruments for the grope-and-cling mechanisms used to contact other cells, not only in the vicinity, but also over remarkable distances. Thus, in a dynamic modification of the "differential adhesion hypothesis" of tissue formation (Steinberg 1962), MSCs in culture or in the embryo may make $\mathrm{Ca}^{2+}$ dependent junctional contacts with other cells of the same or a different kind (for the possibility of heterotypic junction formations in cell culture, see Volk et al. 1987) and may stabilize them or allow re-dissociation until a developmental optimum of cell sorting, aggregation, and positioning has been reached (e.g., Duguay et al. 2003; Perez-Moreno et al. 2003). However, although cell-cell interactions and cell sorting have so far been considered primarily as a short-distance nearest-neighbour relationship of recognition and association (e.g., Steinberg 1962; Takeichi 1988; Duguay et al. 2003), our findings now demonstrate that cells can (via such processus adhaerentes) also attach to one or several distant cells and bring them into close-packed tissue-forming arrays.

Why have these frequent and conspicuous processus adhaerentes escaped detection so far? One reason may be the general lack of comprehensive cell biological studies of cultured MSCs. Further explanations might be their transient nature in cell culture in which they become reduced in number with confluency, and their extreme 

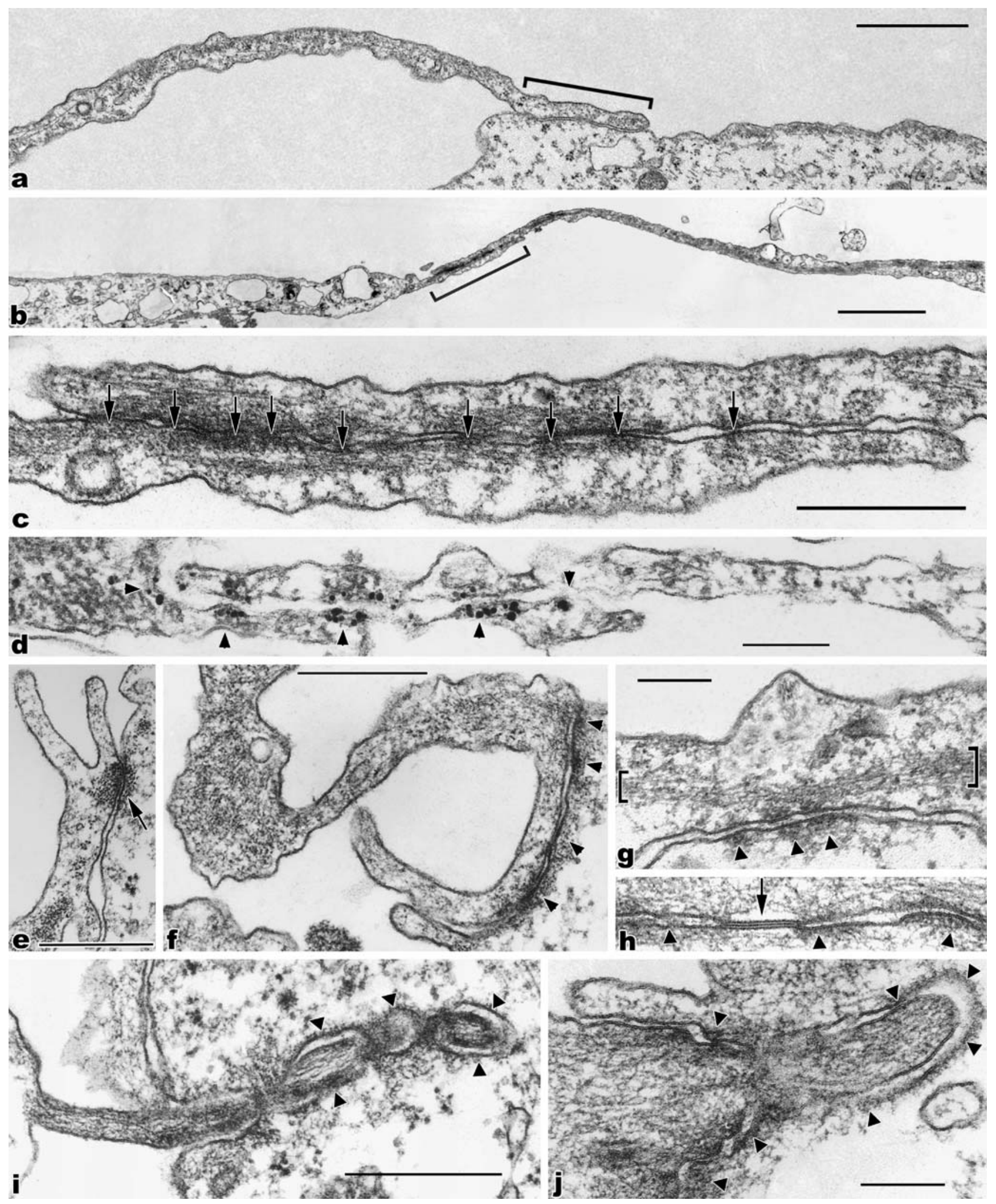

preparative fragility. On the other hand, we have previously noted, in an electron-microscopic study of primary mesenchymal cells and developing mesoderm of the mouse embryo in situ, "the frequency of small punctum adhaerens-like junctions", including some located "within interdigitations of processes of mesenchymal cells" (Franke et 

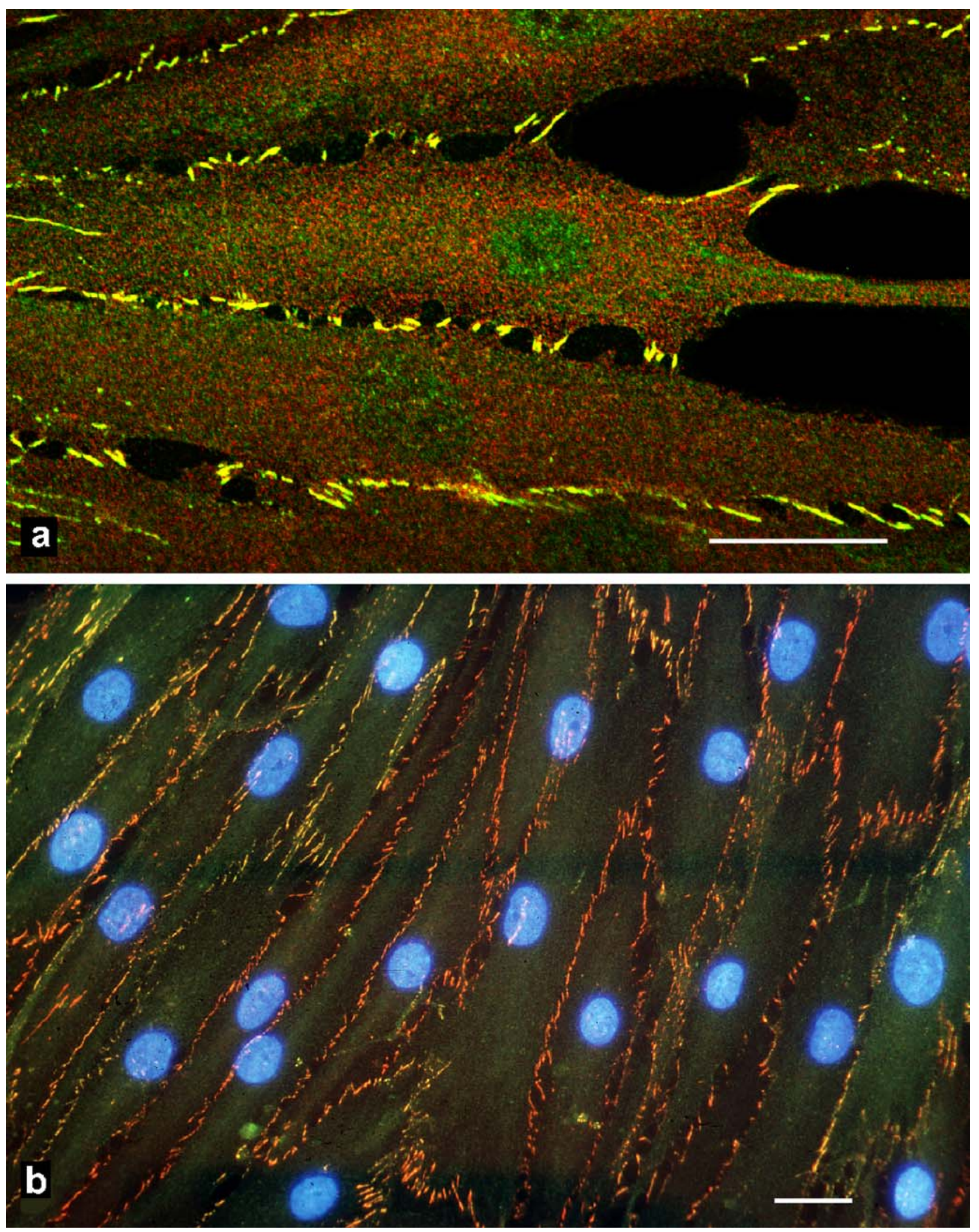
Fig. 11 Double-label immunofluorescence microscopy of a human MSC culture grown to near (a) or complete (b) confluence. The cell cultures were treated with antibodies to $\beta$-catenin (green) in combination with antibodies to cadherin-11 (a, red) or N-cadherin $(\mathbf{b}$, red $)$. Nuclei were stained with DAPI. Note the colocalization of junctional protein markers in the numerous intercellular adherens junction "bridges" that are increasingly reduced in length as the cells become closer-packed. Note also the complete absence of long cell processes, which are typical of sparser cultures. Bars $25 \mu \mathrm{m}$

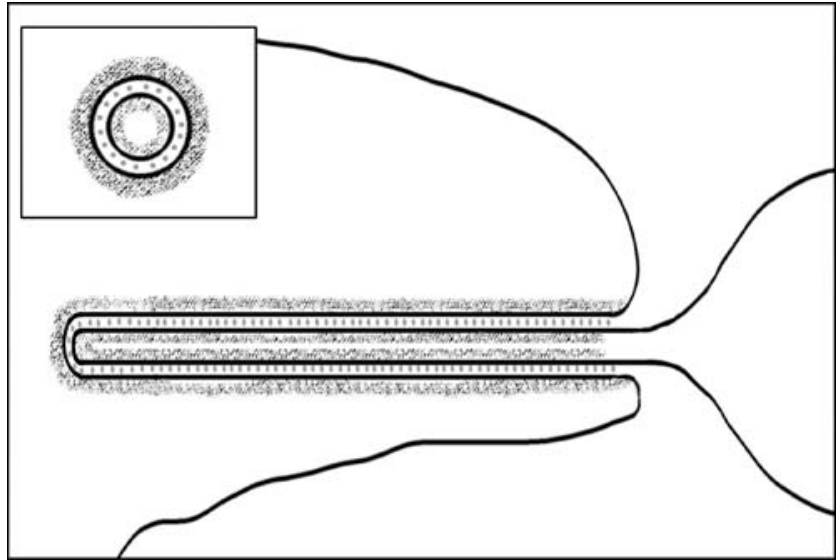

Fig. 12 Representation of a manubrium adhaerens (adhering interlock) between two MSCs, as reconstructed from electron micrographs of ultrathin sections. A cell process from the right-hand cell inserts, in a tightly fitting manner, into a deep cell surface recess of the left-hand cell, as shown in longitudinal section and cross section (insert, upper left). The fused plaque region is indicated by the shaded layer, whereas the intercellular cadherin associations are presented as short punctate bridges

al. 1983; see also Hashimoto and Nakatsuji 1989; Tam et al. 1993). Therefore, we hypothesize that such "organizing" and "interlocking" cell processes are more widespread in embryonic and other tissues than is presently believed and have begun to characterize the molecular composition and developmental roles of the in situ equivalents of such junction-bearing cell processes.

Acknowledgements We thank Michaela Hergt, Edeltraut Noffz, and Heide Schumacher for cell culture work, Volker Eckstein for flow cytometry phenotyping, Martina Schnoelzer and Tore Kempf for MALDI analyses, Jutta Osterholt for expert photography, and Eva Gundel for careful secretarial work.

\section{References}

Alvarez-Dolado M, Pardal R, Garcia-Verdugo JM, Fike JR, Lee HO, Pfeffer K, Lois C, Morrison SJ, Alvarez-Buylla A (2003) Fusion of bone-marrow-derived cells with Purkinje neurons, cardiomyocytes and hepatocytes. Nature 425:968-973

Bieback K, Kern S, Klüter H, Eichler H (2004) Critical parameters for the isolation of mesenchymal stem cells from umbilical cord blood. Stem Cells 22:625-634
Bonilha VL, Finnemann SC, Rodriguez-Boulan E (1999) Ezrin promotes morphogenesis of apical microvilli and basal infoldings in retinal pigment epithelium. J Cell Biol 147:1533-1547

Bretscher A, Edwards K, Fehon RG (2002) ERM proteins and merlin: integrators at the cell cortex. Nat Rev Mol Cell Biol 3: 586-599

Chan MWC, El Sayegh TY, Arora PD, Laschinger CA, Overall CM, Morrison C, McCulloch CAG (2004) Regulation of intercellular adhesion strength in fibroblasts. J Biol Chem 279:41047-41057

Cossart P, Lecuit M (1998) Interactions of Listeria monocytogenes with mammalian cells during entry and actin-based movement: bacterial factors, cellular ligands and signaling. EMBO J 17:3797-3806

Duguay D, Foty RA, Steinberg MS (2003) Cadherin-mediated cell adhesion and tisue segregation: qualitative and quantitative determinants. Dev Biol 253:309-323

Franke WW, Grund C, Jackson BW, Illmensee K (1983) Formation of cytoskeletal elements during mouse embryogenesis. IV. Ultrastructure of primary mesenchymal cells and their cell-cell interactions. Differentiation 25:121-141

Fukuda K (2002) Reprogramming of bone marrow mesenchymal stem cells into cardiomyocytes. C R Biol 325:1027-1038

Gautreau A, Poullet P, Louvard D, Arpin M (1999) Ezrin, a plasma membrane-microfilament linker, signals cell survival through the phosphatidylinositol 3-kinase/Akt pathway. Proc Natl Acad Sci USA 96:7300-7305

Godsel LM, Getsios S, Huen AC, Green KJ (2004) The molecular composition and function of desmosomes. In: Behrens J, Nelson WJ (eds) Cell adhesion. Handbook of Experimental Pharmacology, vol 165. Springer, Heidelberg, pp 137-193

Hämmerling B, Grund C, Boda-Heggemann J, Moll R, Franke WW (2006) The complexus adhaerens of mammalian lymphatic endothelia revisited: a junction even more complex than hitherto thought. Cell Tissue Res 324:55-67

Hamon M, Bierne H, Cossart P (2006) Listeria monocytogenes: a multifaceted model. Nat Rev Microbiol 4:423-434

Hashimoto K, Nakatsuji N (1989) Formation of the primitive streak and mesoderm cells in mouse embryos - detailed scanning electron microscopical study. Dev Growth Differ 31:209-218

Hinescu ME, Gherghiceanu M, Mandache E, Ciotea SM, Popescu LM (2006) Interstitial Cajal-like cells (ICLC) in atrial myocardium: ultrastructural and immunohistochemical characterization. J Cell Mol Med 10:243-257

Hinz B, Pittet P, Smith-Clerc J, Chaponnier C, Meister JJ (2004) Myofibroblast development is characterized by specific cell-cell adherens junctions. Mol Biol Cell 15:4310-4320

Hoffmann I, Balling R (1995) Cloning and expression analysis of a novel mesodermally expressed cadherin. Dev Biol 169:337-346

Horikawa K, Radice G, Takeichi M, Chisaka O (1999) Adhesive subdivisions intrinsic to the epithelial somites. Dev Biol 215:182-189

Irie K, Shimizu K, Sakisaka T, Ikeda W, Takai Y (2004) Roles of nectins in cell adhesion, signaling and polarization. In: Behrens $\mathrm{J}$, Nelson WJ (eds) Cell adhesion. Handbook of Experimental Pharmacology, vol 165. Springer, Heidelberg, pp 343-372

Jiang Y, Jahagirdar BN, Reinhardt RL, Schwartz RE, Keene CD, Ortiz-Gonzalez XR, Reyes M, Lenvik T, Lund T, Blackstad M, Du J, Aldrich S, Lisberg A, Low WC, Largaespada DA, Verfaillie CM (2002) Pluripotency of mesecnyhmal stem cells derived from adult marrow. Nature 418:41-49

Kiener HP, Stipp CS, Allen PG, Higgins JMG, Brenner MB (2006) The cadherin-11 cytoplasmic juxtamembrane domain promotes $\alpha$-catenin turnover at adherens junctions and intercellular motility. Mol Biol Cell 17:2366-2376

Kimura Y, Matsunami H, Inoue T, Shimamura K, Uchida N, Ueno T, Miyazaki Z, Takeichi M (1995) Cadherin-11 expressed in association with mesenchymal morphogenesis in the head, somite, and limb bud of early mouse embryos. Dev Biol 169:347-358 
Kinner B, Zaleskas JM, Spector M (2002) Regulation of smooth muscle actin expression and contraction in adult human mesenchymal stem cells. Exp Cell Res 278:72-83

Knapp AC, Franke WW (1989) Spontaneous losses of control of cytokeratin gene expression in transformed, non-epithelial human cells occurring at different levels of regulation. Cell 59:67-79

Kobielak A, Pasolli HA, Fuchs E (2004) Mammalian formin-1 participates in adherens junctions and polymerization of linear actin cables. Nat Cell Biol 6:21-30

Kostetskii I, Li J, Xiong Y, Zhou R, Ferrari VA, Patel VV, Molkentin JD, Radice GL (2005) Induced deletion of the N-cadherin gene in the heart leads to dissolution of the intercalated disc structure. Circ Res 96:346-354

LaBarge MA, Blau HM (2002) Biological progression from adult bone marrow to mononucleate muscle stem cell to multinucleate muscle fiber in response to injury. Cell 111:589-601

Lan M, Kojima T, Murata M, Osanai M, Takano K, Chiba H, Sawada N (2006) Phosphorylation of ezrin enhances microvillus length via a p38 MAP-kinase pathway in an immortalized mouse hepatic cell line.Exp Cell Res 312:111-120

Langbein L, Grund C, Kuhn C, Praetzel S, Kartenbeck J, Brandner JM, Moll I, Franke WW (2002) Tight junctions and compositionally related junctional structures in mammalian stratified epithelia and cell cultures derived therefrom. Eur J Cell Biol 81:419-435

Luo Y, Kostetskii I, Radice GL (2004) N-cadherin is not essential for limb mesenchymal chondrogenesis. Dev Dyn 232:336-344

Mertens C, Kuhn C, Franke WW (1996) Plakophilins 2a and 2b: constitutive proteins of dual location in the karyoplasm and the desmosomal plaque. J Cell Biol 135:1009-1025

Minguell JJ, Erices A, Conget P (2001) Mesenchymal stem cells. Exp Biol Med 226:507-520

Moll R, Holzhausen H-J, Mennel H-D, Kuhn C, Baumann R, Taege C, Franke WW (2006) The cardiac isoform of $\alpha$-actin in regenerating and atrophic skeletal muscle, myopathies and rhabdomyomatous tumors: an immunohistochemical study using monoclonal antibodies. Virchows Arch 449:175-191

Okazaki M, Takeshita S, Kawai S, Kikuno R, Tsujimura A, Kudo A, Amann E (1994) Molecular cloning and characterization of OB-cadherin, a new member of cadherin family expressed in osteoblasts. J Biol Chem 269:12092-12098

Orlic D, Kajstura J, Chimenti S, Jakoniuk I, Anderson SM, Li B, Pickel J, McKay R, Nadal-Ginard B, Bodine DM, Leri A, Anversa P (2001) Bone marrow cells regenerate infracted myocardium. Nature 410:701-705

Ortiz LA, Gambelli F, McBride C, Gaupp D, Baddoo M, Kaminski N, Phinney DG (2003) Mesenchymal stem cell engraftment in lung is enhanced in response to bleomycin exposure and ameliorates its fibrotic effects. Proc Natl Acad Sci USA 100:8407-8411

Paffenholz R, Kuhn C, Grund C, Stehr S, Franke WW (1999) The arm-repeat protein NPRAP (neurojungin) is a constituent of the plaques of the outer limiting zone in the retina, defining a novel type of adhering junction. Exp Cell Res 250:452-464

Peitsch WK, Hofmann I, Prätzel S, Grund C, Kuhn C, Moll I, Langbein K, Franke WW (2001) Drebrin particles: components in the ensemble of proteins regulating actin dynamics of lamellipodia and filopodia. Eur J Cell Biol 80:567-579

Perez-Moreno M, Jamora C, Fuchs E (2003) Sticky business: orchestrating cellular signals at adherens junctions. Cell 112:535-548

Pittenger MF, Mackay AM, Beck SC, Jaiswal RK, Douglas R, Mosca JD, Morrman MA, Simonetti DW, Craig S, Marshak DR (1999) Multilineage potential of adult human mesenchymal stem cells. Science 284:143-147
Radice GL, Rayburn H, Matsunami H, Knudsen KA, Takeichi M, Hynes RO (1997) Developmental defects in mouse embryos lacking N-cadherin. Dev Biol 181:64-78

Sanger JW, Sanger JM, Jockusch BM (1983) Differences in the stress fibers between fibroblasts and epithelial cells. J Cell Biol 96:961-969

Simonneau L, Thiery JP (1998) The mesenchymal cadherin-11 is expressed in restricted sites during ontogeny of the rat brain in modes suggesting novel function. Cell Adhes Commun 6:431-450

Spees JL, Olson SD, Ylostalo J, Lynch PJ, Smith J, Perry A, Peister A, Wang MY, Prockop DJ (2003) Differentiation, cell fusion, and nuclear fusion during ex vivo repair of epithelium by human adult stem cells from bone marrow stroma. Proc Natl Acad Sci USA 100:2397-2402

Steinberg MS (1962) On the mechanism of tissue reconstruction by dissociated cells. I. Population kinetics, differential adhesiveness, and the absence of directed migration. Proc Natl Acad Sci USA 48:1577-1582

Steinberg MS, McNutt PM (1999) Cadherins and their connections: adhesion junctions have broader functions. Curr Opin Cell Biol 11:554-560

Straub BK, Boda J, Kuhn C, Schnoelzer M, Korf U, Kempf T, Spring H, Hatzfeld M, Franke WW (2003) A novel cell-cell junction system: the cortex adhaerens mosaic of lens fiber cells. J Cell Sci 116:4985-4995

Takai Y, Nakanishi H (2003) Nectin and afadin: novel organizers of intercellular junctions. J Cell Sci 116:17-27

Takeichi M (1988) The cadherins: cell-cell adhesion molecules controlling animal morphogenesis. Development 102:639-655

Tam PPL, Williams EA, Chan WY (1993) Gastrulation in the mouse embryo: ultrastructural and molecular aspects of germ layer morphogenesis. Microsc Res Tech 26:301-328

Tepass U, Truong K, Godt D, Ikura M, Peifer M (2000) Cadherins in embryonic and neural morphogenesis. Nat Rev Mol Cell Biol 1:91-100

Terada N, Hamazani T, Oka M, Hoki M, Mastalerz DM, Nakano Y, Meyer EM, Morel L, Petersen BE, Scott EW (2002) Bone marrow cells adopt the phenotype of other cells by spontaneous cell fusion. Nature 416:542-545

Urbanek K, Quaini F, Tasca G, Torella D, Castaldo C, Nadal-Ginard B, Leri A, Kajstura J, Quaini E, Anversa P (2003) Intense myocyte formation from cardiac stem cells in human cardiac hypertrophy. Proc Natl Acad Sci USA 100:10440-10445

Vaheri A, Carpen O, Heiska L, Helander TS, Jaaskelainen J, Majander-Nordenswan P, Sainio M, Timonen T, Turunen O (1997) The ezrin protein family: membrane-cytoskeleton interactions and disease associations. Curr Opin Cell Biol 9:659-666

Vasioukhin V, Bauer C, Yin M, Fuchs E (2000) Directed actin polymerization is the driving force for epithelial cell-cell adhesion. Cell 100:209-219

Vassilopoulos G, Wang P-R, Russell DW (2003) Transplanted bone marrow regenerates liver by cell fusion. Nature 422:901-904

Verfaillie CM (2002) Adult stem cells: assessing the case for pluripotency. Trends Cell Biol 12:502-508

Volk T, Cohen O, Geiger B (1987) Formation of heterotypic adherenstype junctions between L-CAM-containing liver cells and ACAM-containing lens cells. Cell 50:987-994

Wagner W, Wein F, Seckinger A, Frankhauser M, Wirkner U, Krause U, Blake J, Schwager C, Eckstein V, Ansorge W, Ho AD (2005) Comparative characteristics of mesenchymal stem cells from human bone marrow, adipose tissue, and umbilical cord blood. Exp Hematol 33:1402-1416

Wang X, Willenbring H, Akkari Y, Torimaru Y, Foster M, Al-Dhalimy M, Lagasse E, Finegold M, Olson S, Grompe M (2003) Cell fusion is the principal source of bone-marrow-derived hepatocytes. Nature 422:897-901

Ying Q-L, Nichols J, Evans EP, Smith AG (2002) Changing potency by spontaneous fusion. Nature 416:545-548 